Belo Horizonte (MG), Brazil

Department of Pharmacology, Universidade Federal de Minas Gerais (UFMG),

Belo Horizonte (MG), Brazil

Juliana Garcia Carneiro, Patrícia de Araújo Pereira Department of Pharmacology, Universidade Federal de Minas Gerais (UFMG), Belo Horizonte (MG), Brazil

Humberto Correa Mental Health Department, School of Medicine, Universidade Federal de Minas Gerais (UFMG), Belo Horizonte (MG), Brazil

Antonio Lúcio Teixeira Department of Internal Medicine, School of Medicine, Universidade Federal de Minas Gerais (UFMG), Belo Horizonte (MG), Brazil

Financial support: None

Conflict of interests: None

References

1. da Rocha FF, Correa H, Teixeira AL. A successful outcome with valproic acid in a case of mania secondary to stroke of the right frontal lobe. Prog Neuropsychopharmacol Biol Psychiatry. 2008;32(2):587-8.

2. Wijeratne C, Malhi GS. Vascular mania: an old concept in danger of sclerosing? A clinical overview. Acta Psychiatr Scand Suppl. 2007:434:35-40.

3. Chemerinski E, Levine SR. Neuropsychiatric disorders following vascular brain injury. Mt Sinai J Med. 2006;73(7):1006-14.

4. Zanetti MV, Cordeiro Q, Busatto GF.Late onset bipolar disorder associated with white matter hyperintensities: a pathophysiological hypothesis. Prog Neuropsychopharmacol Biol Psychiatry. 2007;31(2):551-6.

\section{Efeitos do abuso do álcool relacionados à violência doméstica nos filhos: um levantamento bibliográfico}

Effects of alcohol albuse on domestics violence against children: a bibliographical survey

\section{Sr. Editor}

Numerosos estudos têm documentado significativas associações entre o uso de álcool e problemas com a perpetuação da violência doméstica e abuso físico e sexual da criança. ${ }^{1}$ Estudos de adultos filhos de alcoolistas, e de adultos que experienciaram o abuso sexual ou físico na infância, demonstram que ambos os grupos são descritos como de risco aumentado para ansiedade, depressão, somatização, impulsividade, abuso de substâncias, problemas com relacionamentos e intimidade, ${ }^{2}$ e risco aumentado para perpetração e vitimização pela violência marital do adulto. ${ }^{3}$

O estudo da história de violência doméstica (HVD) requer uma compreensão das interconexões complexas entre o abuso e a negligência à criança, bem como da transmissão da violência às gerações seguintes. Crianças que foram expostas à violência mostram uma variedade de resultados negativos, precocemente na infância. A identificação da HVD em famílias de alcoolistas por profissionais de saúde mental tem um efeito potencial positivo na saúde das crianças, podendo protege-las das disfunções psicológicas e comportamentais durante todo ciclo de vida. Daí a importância da intervenção precoce em crianças que sofrem problemas relacionados ao alcoolismo familiar e violência doméstica.

Partindo da premissa de que HVD e história de alcoolismo familiar (HAF) são consideradas componentes familiares importantes da trajetória do desenvolvimento, que conduz a posteriores problemas com violência, uso de substâncias e outros problemas psiquiátricos entre os descendentes nestas famílias, ${ }^{3}$ foi realizada uma revisão bibliográfica nas bases de dados MedLine e Lilacs entre o período de janeiro de 1997 a janeiro de 2007. Esta revisão teve como finalidade compreender melhor as inter-relações entre HAF e HVD e a repercussão na saúde mental e no desenvolvimento das crianças que vivem em um contexto com estas situações associadas.

Dos resultados deste levantamento, foi encontrado um total de 182 artigos, o que evidência um crescente interesse dos pesquisadores sobre esta temática. Entretanto, alguns pontos chamaram a atenção em virtude de determinados aspectos, tais como:

1) Estudos examinam os potenciais efeitos adversos aditivos e interativos na infância de HVD e HAF e os resultados em longo prazo para adolescentes e adultos (problemas com álcool e outras substâncias e perpetração ou vitimização da violência), mas não em curto-prazo, ainda na infância;

2) Os pesquisadores geralmente mensuram o alcoolismo parental e a violência contra a criança de forma isolada um do outro, não estabelecendo uma relação conclusiva entre estas variáveis e o risco relativo de problemas posteriores;

3) Os estudos nacionais focalizam-se na descrição dos serviços de atendimento e caracterização da clientela atendida; entretanto, aqueles que fazem menção a problemas de uso de álcool relacionado à violência doméstica não utilizam instrumentos adequados para avaliar tal questão;

4) As amostras dos estudos são constituídas basicamente de adultos jovens, do sexo masculino e suas parceiras, em sua maior parte perpetradores de violência ou alcoolistas, o que pode superestimar a relação destas variáveis. Além disso, aqueles que incluíram homens e mulheres, raramente examinaram as diferenças de gênero;

5) A maioria dos estudos utilizou desenhos de coorte transversal retrospectivo e foram assim suscetíveis aos problemas de recordação e respostas enviesadas;

6) Somente um estudo avaliou HVD e HAF combinadamente ainda na infância. ${ }^{4}$ 
Mediante o exposto, podemos constatar que pesquisas que examinem resultados das crianças com HAF, considerando também concomitante à HVD, avaliando-se os efeitos da história de álcool mediados pela história de violência ou vice-versa, mostram-se de extrema relevância.

Daniela Viganó Zanoti-Jeronymo Universidade Estadual do Centro Oeste (UNICENTRO), Guarapuava (PR), Brasil Ronaldo Laranjeira, Neliana Buzi Figlie Unidade de Pesq uisa em Álcool e Drogas (UNIAD), Departamento de Psiquiatria, Escola Paulista de Medicina, Universidade Federal de São Paulo (UNIFESP), São Paulo (SP), Brasil

Financiamento: Inexistente

Conflito de interesses: Inexistente

\section{Referências}

1. Widom CS, Hiller-Sturmhofel S. Alcohol abuse as a risk factor for and consequence of child abuse. Alcohol Res Health. 2001;25(1):52-7.

2. Harter ST, Taylor TL. Parental alcoholism, child abuse, and adult adjustment. J Subst Abuse. 2000;11(1):31-44.

3. Chermack ST, Stoltenberg SF, Fuller BE, Blow FC. Gender differences in the development of substance-related problems: the impact of family history of alcoholism, family history of violence, and childhood conduct problems. J Stud Alcohol. 2000;61(6):845-52.

4. Fuller BE, Chermack ST, Cruise KA, Kirsch E, Fitzgerald HE, Zucker RA. Predictors of aggression across three generations among sons of alcoholics: relationships involving grandparental and parental, child aggression, marital aggression and parenting practices. J Stud Alcohol. 2003;64(4):472-83.

\section{An unusual case report: treatment of cocaine-dependent patient with an atypical antipsychotic}

\section{Um relato de caso incomum: tratamento de um paciente dependente de cocaína com antipsicótico atípico}

Dear Editor,

The patient is a 27-year-old, woman, who was diagnosed with dependence of cocaine as a teenager. She has a history of multiple admissions for clinical treatment and subsequent partial response to antipsychotic medication. Over time, she has been prescribed haloperidol and risperidone. The side effects included lethargy.

On admission, she was expressing rapid discourse, mainly of a persecutory nature. She was started on olanzapine at a dose of $2.5 \mathrm{mg}$ daily, which was increased to $7.5 \mathrm{mg}$ on day 7 and to $10 \mathrm{mg}$ on day 14 (an oral dose administered at night). Her psychotic symptoms did not persist. Routine physical examination and investigations were all within normal limits including liver enzymes. After 6 weeks of a dose of $10 \mathrm{mg} /$ day, her dependence symptoms had returned to their pre-morbid levels. ${ }^{1}$

The neuropharmacological profile of the atypical antipsychotic olanzapine is consistent with a potentially useful medication for cocaine abuse, confirming the hypothesis that patients treated with olanzapine have reduced cocaine craving and abuse. The US FDA has approved a limited number of treatments for alcohol, nicotine and opioid dependence; however, no treatments for other abused drugs such as marijuana, cocaine or methamphetamine are approved. ${ }^{1}$ Because cocaine delivers a particularly positive and reinforcing high, most users do not seek treatment voluntarily until the behavioral patterns have resulted in significant impairment in function or health problems. Craving for cocaine is often so intense that an individual needs to be initially entered into residential treatment in order to establish abstinence from the drug. Treatment must be multimodal, including medical, psychological, and social strategies to help the patient establish and maintain abstinence. ${ }^{2}$

The history of hypersensitivity to olanzapine in this patient was exclusio, included experiences of psychotic in this patients dementia and the use of other psychotropic medications. Baseline laboratory testing included a chemistry screen, complete blood count, and urinalysis. The patient received urinary pregnancy testing prior to starting medications, and at monthly intervals throughout the study. ${ }^{3}$

As a dopamine antagonist, olanzapine may worsen this hedonic deregulation and this may have made it difficult for olanzapine-treated subjects to remain abstinent.

Risperidone was found to be effective in reducing craving and relapse among cocaine-dependent schizophrenics in an open trial. ${ }^{2}$

Olanzapine was well tolerated. The adverse events reported included: weight gain (40\%), drowsiness (40\%), constipation (13\%), dizziness $(10 \%)$, dry mouth $(7 \%)$, nausea $(7 \%)$, restlessness $(7 \%)$ and urticaria $(3 \%)$. But in this case, there were not any of these events. The history of hypersensitivity to olanzapine in this patient was exclusion. ${ }^{4}$

Further studies to clarify this point and the precise pharmacology effect would be helpful. Olanzapine may be superior to traditional neuroleptics for the treatment of cocaine dependence due to its less severe side effect profile. ${ }^{5}$ This case was intended to determine if olanzapine showed any promise for the treatment of cocaine dependence. Further controlled research is warranted to more precisely determine the effect of olanzapine in this case.

Carlos Simon Guzman, José Ângelo Barletta Crescente Jr Psychiatry Institute, Clinical Hospital, Medical School, Universidade de São Paulo (USP), São Paulo (SP), Brazil 